\title{
マダイにおける櫛鱗の棘の発達についで
}

\author{
小林久雄·戸谷繁 \\ (1964 年 5 月 11 日受理)
}

\section{STUDIES ON THE DEVELOPMENT OF CTENII IN THE CTENOID SCALES OF RED SEA BREAM CHRYSOPHRYS MAJOR T. ET S.}

\author{
Hisao Kobayasi and Hazime Toya**
}

We observed the developmental process of ctenii in the ctenoid scales of red sea bream Chrysophrys major TEMMINCK et SCHLEGEL in comparison with that of common sea bass Lateolabrax japonicus CUVIER et VALENCIENNES, and the following results were obtained.

1) In this fish, we found another example of a similar destruction phenomenon in fully formed spine of ctenoid scales to what we ascertained in that of common sea bass (KoBAYASI and MiwA, 1964).

2) But in this species, they formed a split between the proximal and the middle portion of spine just before the starting of destruction phenomenon, and a similar split emerged between the middle and the distal pointed portion some time after the formation of primary split.

3) Another destruction was observed that extended from distal portion to anterior direction beside one or both side destruction of middle portion of split.

4) On the observation by sectioned materials, the scale increases in size and thickness by the addition of scale substance in the direction of scale margin and lower surface, but it does not on the upper surface.

5) The fact above-mentioned in 4) coincides with that of goldfish by HIYAMA and ICHIKAYA (1954) and YAMADA (1961), but it does not with the contents of HaSE's paper (1911).

6) If the HASE's opinion is correct, the old spinal bases of the ctenoid scale should be imbedded in the scale substance, but our observation was not so in fact.

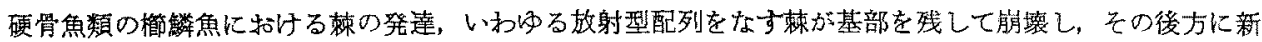
しく新栜を形成する過程については，小林・三輸（1964）がスズキに执いて観察し報告したが，垔だ多くの

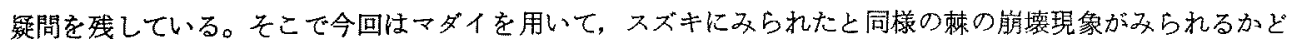
らかを確かめ，スズキのそれと比較するとともに，さらに鱗の切片を作成することによつて，その形成の過 程を立体的に吟味し上うとしてこの研究を行なつた。

\section{材料および方法}

この研究に使用したマダイの稚魚の標本は愛知県の三河湾産の規準体長 $3.7 \sim 26.0 \mathrm{~cm}$ の䄪 55 倜体で, はずフォルマリン漬の標本を水洗後，鱗をはがしてこれを $5 \%$ \% NaH に約 1 日間漫し，ついでこれを 1 \%の Alizarin S t適度に加えた MALL's solution の中に移して1〜2 日垎いて染色して後にブレパラー トを作成してこれを観察した。切片作成の場合にはVON EBNER 氏液の中に約 1 3 日位浸して鱗を脱灰 して, 後に過飽和の $\mathrm{NaCl}$ 夜で酸を除き, ついで1\%の Eosin で染色後パラフィン切片を作成し,プレパ ラートを作つて锶察した。

*この報告の内容は昭和 39 年 4 月 3 月の日本水産学会の年会で発表した。

**受知学芸大学生物学教室 (Dept. Biol., Aiti Gakugei Univ., Okazaki, Japan). 


\section{観 察 結 果}

まず表面的観察に捻いて，完成された棘の崩壤は，その最も初期に棘の基部と中間部を区切るひび割れの ような切れ目（以下これを切断面と記す）が生ずる。この切断面は崩壊現象を起こすずてての棘に，これが 終るまで存在し，瞬の辺縁出るいは新しく生ずる新棘原基の辺縁とも一致しなく全く別のものである。この 切断面ができて後，棘尖端部の後方の，鱗の辺縁部がやや突出しはじめ，それ之同時に切断面あたりに微粒 状をなす新棘物質が現われる。その後の崩壊過程は表面的観察に特いては 3 つの型に分かれる。すなわち棘 の中間部の片側から崩填が進む場合を仅に第 1 型とすれば，第 2 型はその両側から進む場合であり，さらに 今回はじめて気づいた棘の先端から基部の方向と進む第 3 型を知つた。るず中間部の片側あるい虫両側が 進む崩環はちようど基部と中間部を区切る切断面を境にして，基部を残して中間部のみが滑かに崩壊されて くる。中間部がある程度この崩壊が進行するうちに新たに揀の失端部と中間部を区切る第 2 の切断面を生ず る。まれに第 2 のものはもつと早く第 1 と同じ頃生ずることもある。崩墁はこの 2 つの切断面を境にして, 头端部と基部を除いて中間部のみに起こつて,ついには棘質は汪とんどなくなる。その後中間部と断絶され た尖端部は、しばらく残つてはいるが,ついには消失してしまう。この間にはじめ顆粒状であつた新棘物質は たがいに固着してほぼ心缄形の棘の原基を形成し，やがてこれが次の新棘に成長していく。結局は崩壊を起 こす棘はその基部を残して，その後方に新棘が形成されこれを絽返して棘列を形成することになるのである。 またいつぽ棘の尖端部から基部の方向ずな和ち前方に進行するその崩壊は新棘物質の形成が中間部から崩 堙するものより早期に起こつて，ちようど旧棘を包团するような形に新棘の原基が生ずる上うな場合が多い。 まず尖つていた棘の先端が丸味を物びてきて，やがてその尖端部がほとんど崩壤してしまうと新棘物質が归 棘を追いこして前進成長し，尖端部から進んできた崩填が次第に中間部に及んで, 中間部もその一部を残して 全く消失し，ちょうど新棘が旧棘の中間部の端にくいこんでいるょうな状態になる。として中間部が全く消

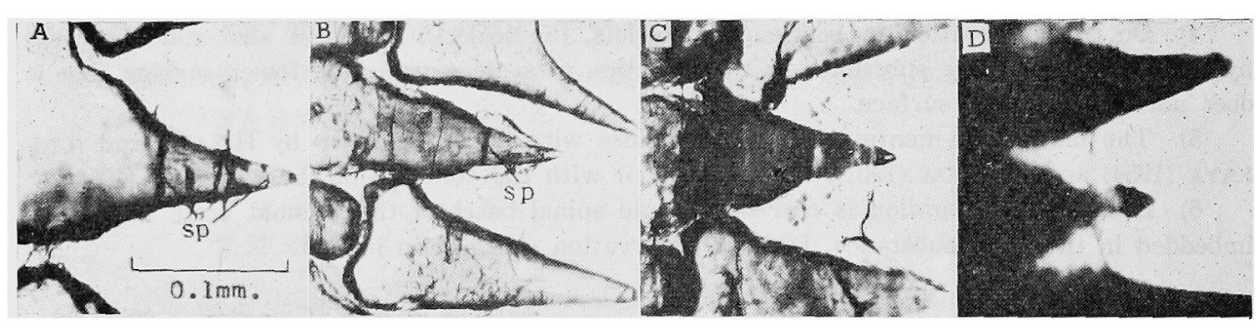

Fig. 1. Both side destruction of spines.

A: showing primary and secondary splits, B: showing primary split and beginning of new spine formation, $C$ : showing stage just before middle portion melt way, $D$ : showing remnant of apical pointed portion.
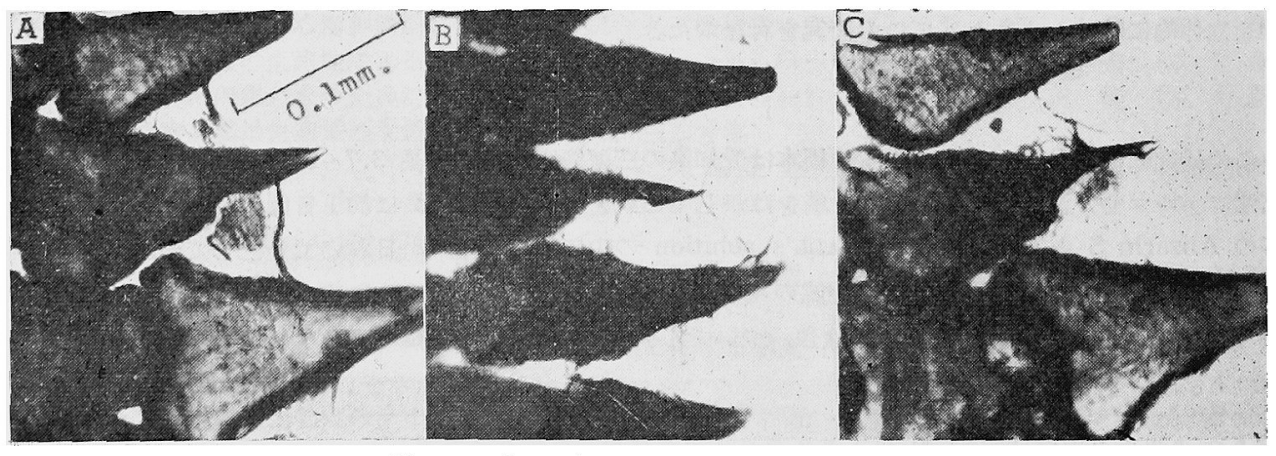

Fig. 2. One side destruction of spines. 

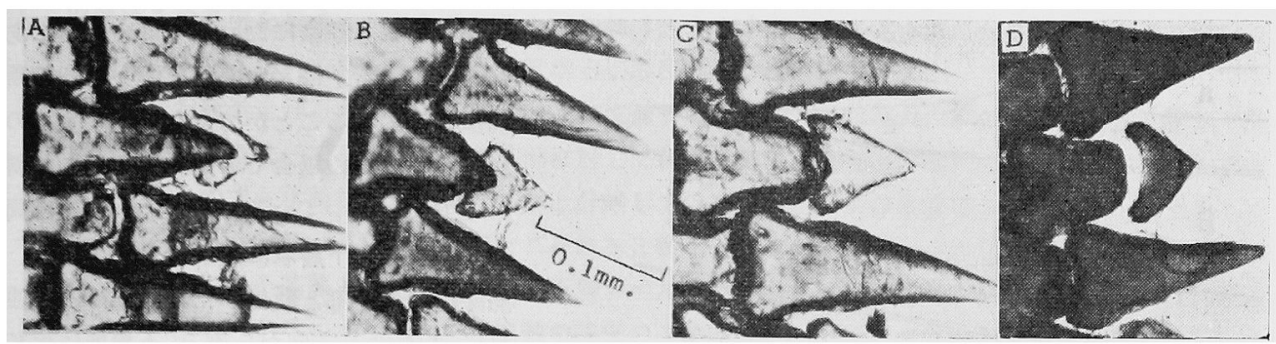

Fig. 3. The third type destruction of spines. Apical and middle portion gradually destruct from apex to spinal base direction.

D: showing destruction finished and a new spine formed.

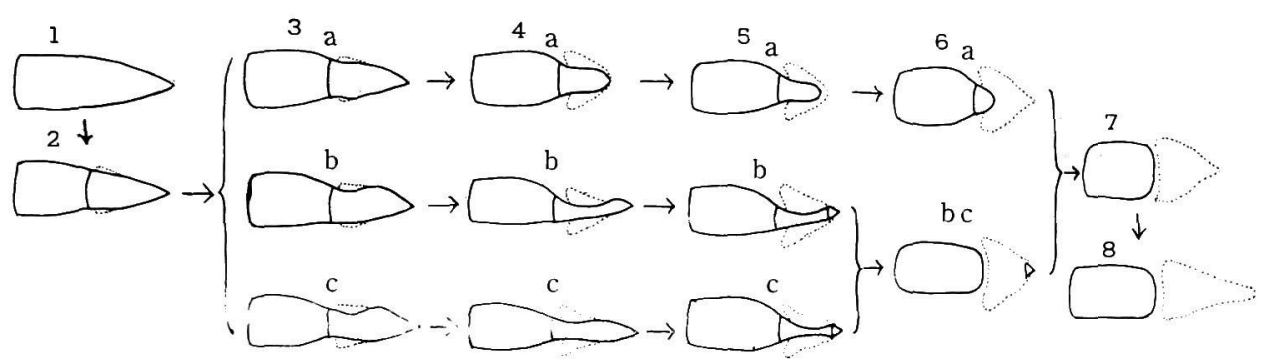

Fig. 4. Diagramatic figures showing order and three types of spine destruction and new spine formation by superficial observation. Dotted lines showing anlage or newly formed young spines.

失してしまうと，ついには旧棘は切断面によつて断絶された基部のみを残し新棘が完成されていくのである。 しかしこの第 3 型の場合は中間部から先に崩壊しはじめる棘のような尖端部と中間部をし切る切断面の形成 は認められない。このよ5にして順次にその 基部を残して新棘が付加されることによつて 棘数を增し，辺縁棘のみが完全棘で，それよ り前方のものは基部のみである放射型排列の 棘列をるつ櫛鱗が形成されるわけである。

以上は表面的観察の結果であるが, この崩 環過程を切片によつて観察することは頗る困 難であつた。ということはほとんどすべての 棘列は放射状に位置し前後の方向に正しく位 置しているあのは中央の 1 列のみであるから， いかにミクロトームの刃を棘切に平行に当る

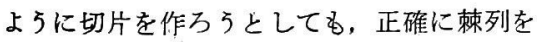
糋断することは極めてむずかしく，また完全 な棘縦断面を立体的に観察できたとしてもそ れが表面からみた棘の崩壊過程のどの時期に 相当するかを正確に見極めることはこれまた 極めて困難である。それゆる切片による観察 はできるだけ多数の材料によつて推察するよ り任方がなかつた。

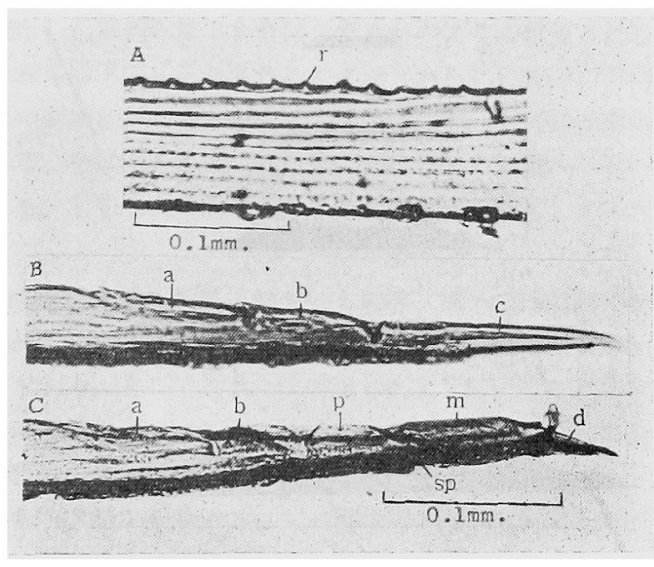

Fig. 5. Longitudinal section of scales.

A: showing scale substance is constructed in many layers, $B$ and $C$ : showing section of spined area, $a$ and $b$ : proximal portion of old spines, c: new formed spine, $\mathrm{p}, \mathrm{m}$ and $\mathrm{d}$ : proximal or basal, split. middle and distal portion of spines. 

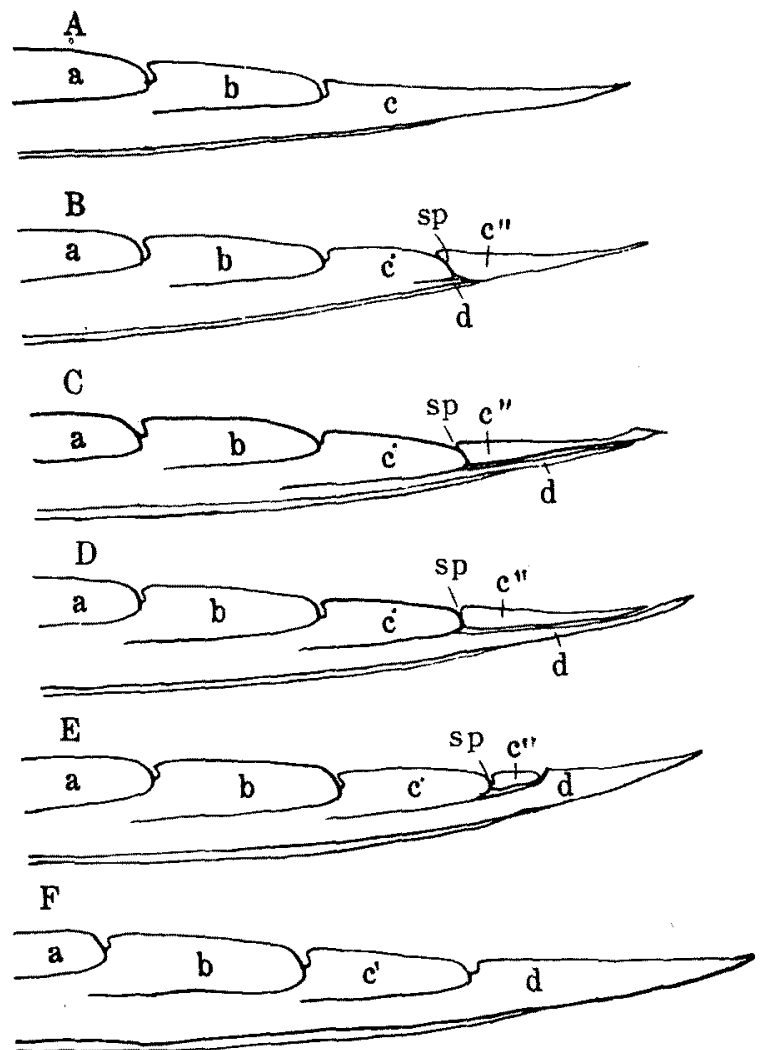

A

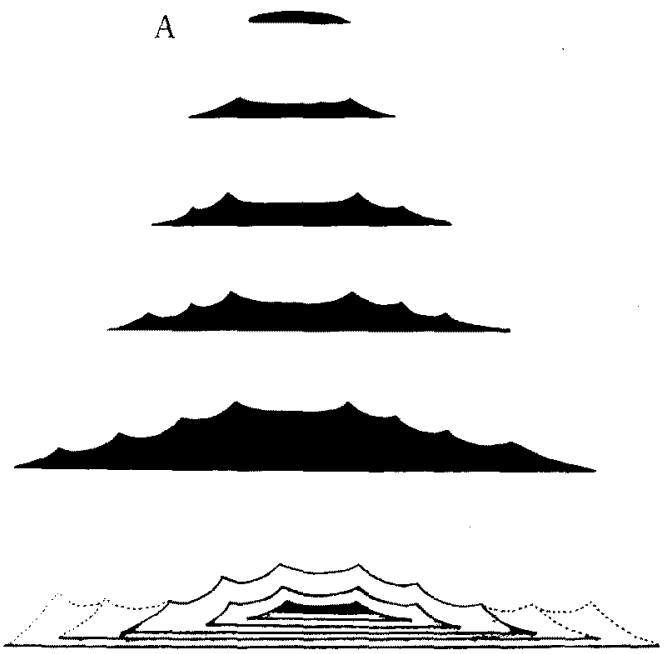

HASE

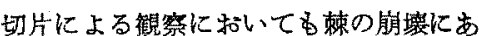
たつて生ずる基部と中間部を境とする切断 面は明瞭にみることができた。しかるるの 裂目はい寸゙れの場合であ後方に向加つて斜 めの方向をとつている。またとれとほほ同 じ时期にとの下層域に新棘物質が生ずる。 崩壊は楝の基部と断絶した中間部のみが独 自にあらゆる方向から進み，下首域に生し た新棘物質がかなり成長し，中間部の溶解 がさらに進さと新棘が旧棘の失端部を前方 に追いこてて成長する。中間部と尖端部は その一部を残して全く崩燷し去り，新棘が 完全柬に近つく。やがて中間部の一部る消

Fig. 6. Diagramatic figures showing order of destruction of spine and new spine formation by sectioned preparates.

$a$ and $b$ : basal portion of old spines, $\mathrm{c}$ : completely formed marginal spine, $c^{\prime}$ : basal portion of marginal spine or just destructed marginal spines, $c^{\prime \prime}$ : middle and distal portion of marginal spines, d: newly formed marginal spines, sp: splits.
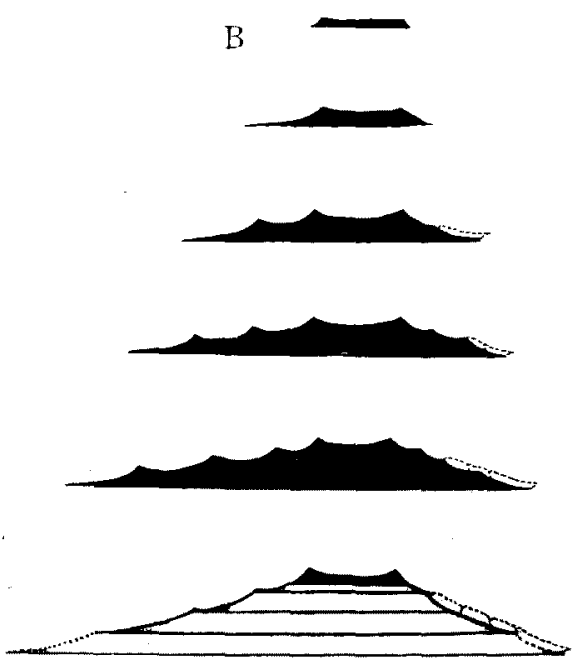

KOB AYASI AND TOYA

Fig. 7. Diagramatic figures showing scale growth by our opinion (B) in comparison with HASE's one (A). 
失し，旧棘はその基部を残すのみとなる。そして新棘はすす亦す発羍して完全棘になる。切片による観察に 特いては崩滇の中期に棘の中間部と冬端部を区切る切断面はついに観察できなかつた。

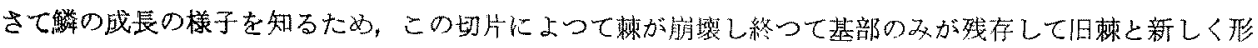

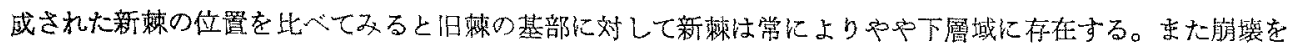
起こしつつあるものでも新棘物質は旧棘の基部と分鼾している中間部招よで尖端部より下層域加ら発生して

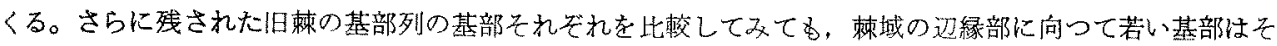
れより古くて前方にある基部よりもすべてより下層レベルに位置していることが，鱗の実質の尿の流れを追 求してみると明瞭にわかる。またこれらの旧棘の基部の上面にはいかに繗が成長しても全く鱗物質は添加さ れない。すなわち旧棘として残存した基部は鱗物質の外面への添加によつて鱗の实質内に埋没することはな く，常に鱗の最上㬝に位置している。

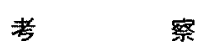

一般に櫛鱗は特別の場合を除きその成屒とともに棘数を堌加する。1本の棘がある程度成長すると，この

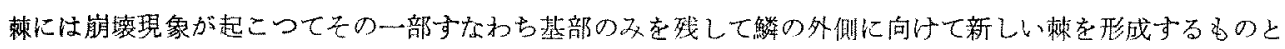
思われる。この萠率の過程をすてに報告されているスズキの場合（小林・三輸，1964）と比较してみると，

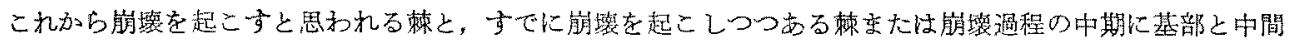
部の境怙よび尖端部と中間部の境に必らず切断面が生ずることがスズキのそれと違うところと思われる。勿 論この切断面は成長の途中にある棘，あるいは新しく完成した棘には全くみられず，また梀列の1列如きに 切断面が生じている状態がしばしば観察できる点で，棘の成長がその初期発生から洘兑て1列赫さに発生し てくる点からして，この棘に切断面が生ずる現象が崩裴の1段階であることに相違ないと考兄られるのであ る。切断面の生ずることは切片に上つても䘽察でるが，その発生機棈については和からないとしても，崩 瓄の進行中は中間部上旧楝基部なたは必端部は切断面によつて全くつながりがなくなる。このことは表面観

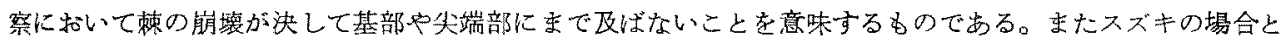
らがつてマダイに括いては棘の头端部から中間部への方向に准む別型の崩壞があることが沢山観察できた。

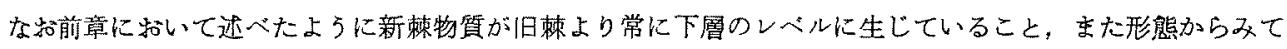
崩買あるいは溶解物質（？）上も考光られるるのが棘化した新棘物質より分泌されるかのよ5に想像される 位置をとつていること。また中間部の溶解がその棘の紝る下下面からなされることなどから鱗の成長の方向

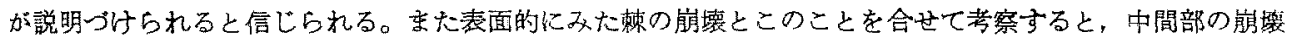

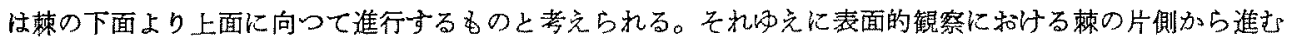

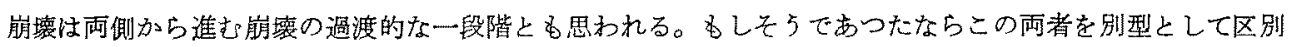

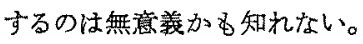

さてこれまでに鱗の成長を，魚を一定期間飼育することによつて観察されているのは，すべて円鱗魚であ ク，櫛鱗魚に执いてはまだなされていない。円鱗の成長についてはかなりよくかかつていたが，上記のよう

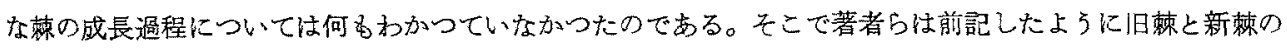
立体的位置の比較によつて轓の成長は勿論，䚬をのるのの成長についてるこれを再吟味することができたの である。すなわち鱗の成長がその辺縁と下面にのみ准むるので, 上面には鱗物質の添加は行なわれないこと を再確認することができた。この事实は金魚について飼育実験加ら報告されている檜山・市川(1952), 山田

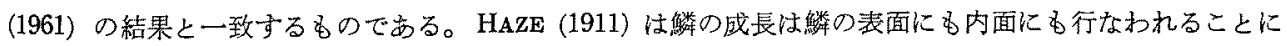

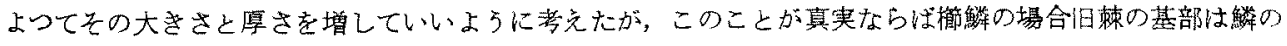

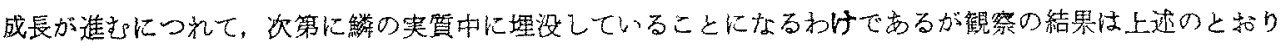

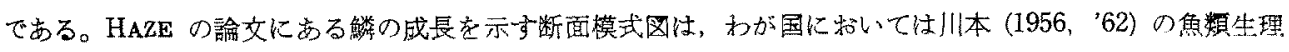
学にす方用されているが，これは Fig. 7 の(B)上うに改めるべきであると思われる。 
摘 要

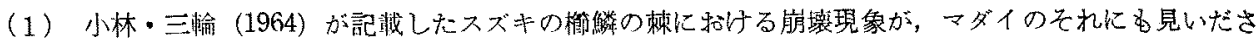
れた。

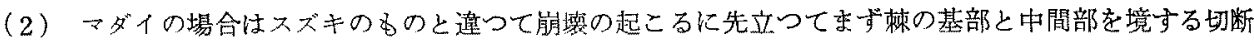

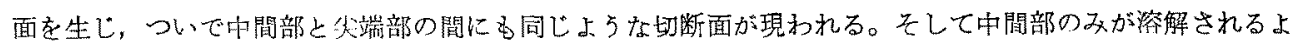
万に消失し，ついは残された尖端部子消失し，基部だけが残存する。

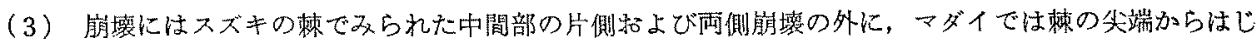
まつて基部の方向に向 5 すがある。

（4）切片による観察によつて，鱗物質は鱗の辽緑特よび下面にのみに添加されることによつて，鳞はそ の大きさや厚さを增大するが，鱗の上面には鱗物質の添加は行なわれないことがわかた。

（5）上記 (4) のことは檜山・市川（1954）および山田（1961）が，とるに金魚の円镂の成長について研 究された結果と一致し，HASE（1911）の論文の内容とは違ていている。

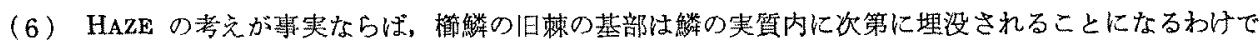
あるが事実は決してそ5でないことが実証された。

\section{謝 辞}

滗を括くにあたつて，この研究に使用したマダイの稚魚の多数の標本を割受して下さつた，東大伊川津水 座実験所の平野助教授と，稚魚の一部の種名を同定をして下さつた九大亦産学教室の塚原教授に讙んで感謝 の意を表する。

\section{文献}

1) HASE, A.: Die Morphologische Entwicklung der Ktenoidschuppen. Anat. Anz., 40, 330 356 (1911).

2) Htyama, Y. and IChikawa, R.: A Method to Mark the Tinne in the Scales and Hard Tissue of Fishes to See Their Growth. Jour. Ichthyol., $2(3 \sim 4), 156 \sim 167$ (1952).

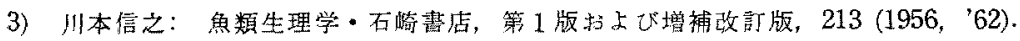

4) 小林久雄・三輸満敏： スズキLateolabrax japonicus CUVIER et VALENCIENNES の稚魚の鱗の初

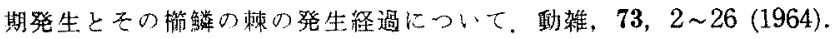

